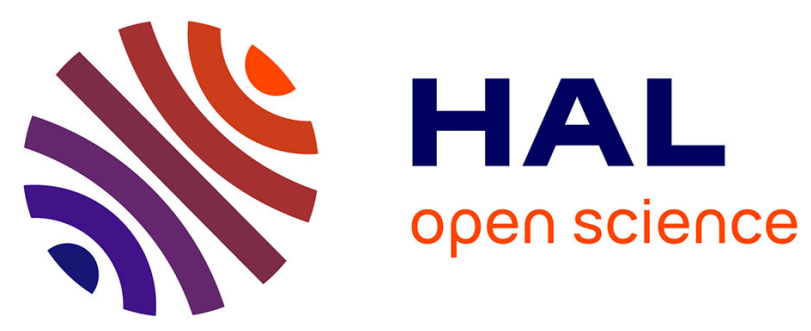

\title{
Detection and molecular analysis of West Nile virus infections in birds of prey in the eastern part of Austria in 2008 and 2009
}

\author{
Eveline Wodak, Susanne Richter, Zoltán. Bagó, Sandra Revilla-Fernández, \\ Herbert Weissenböck, Norbert Nowotny, Petra Winter
}

\section{To cite this version:}

Eveline Wodak, Susanne Richter, Zoltán. Bagó, Sandra Revilla-Fernández, Herbert Weissenböck, et al.. Detection and molecular analysis of West Nile virus infections in birds of prey in the eastern part of Austria in 2008 and 2009. Veterinary Microbiology, 2011, 149 (3-4), pp.358. 10.1016/j.vetmic.2010.12.012 . hal-00683508

\section{HAL Id: hal-00683508 https://hal.science/hal-00683508}

Submitted on 29 Mar 2012

HAL is a multi-disciplinary open access archive for the deposit and dissemination of scientific research documents, whether they are published or not. The documents may come from teaching and research institutions in France or abroad, or from public or private research centers.
L'archive ouverte pluridisciplinaire HAL, est destinée au dépôt et à la diffusion de documents scientifiques de niveau recherche, publiés ou non, émanant des établissements d'enseignement et de recherche français ou étrangers, des laboratoires publics ou privés. 


\section{Accepted Manuscript}

Title: Detection and molecular analysis of West Nile virus infections in birds of prey in the eastern part of Austria in 2008 and 2009

Authors: Eveline Wodak, Susanne Richter, Zoltán. Bagó, Sandra Revilla-Fernández, Herbert Weissenböck, Norbert

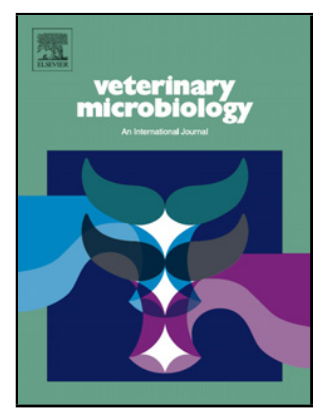
Nowotny, Petra Winter

PII: S0378-1135(10)00585-7

DOI: doi:10.1016/j.vetmic.2010.12.012

Reference: VETMIC 5124

To appear in: $\quad$ VETMIC

Received date: $\quad 20-9-2010$

Revised date: $\quad 22-11-2010$

Accepted date: $\quad 7-12-2010$

Please cite this article as: Wodak, E., Richter, S., Bagó, Zn., Revilla-Fernández, S., Weissenböck, H., Nowotny, N., Winter, P., Detection and molecular analysis of West Nile virus infections in birds of prey in the eastern part of Austria in 2008 and 2009, Veterinary Microbiology (2010), doi:10.1016/j.vetmic.2010.12.012

This is a PDF file of an unedited manuscript that has been accepted for publication. As a service to our customers we are providing this early version of the manuscript. The manuscript will undergo copyediting, typesetting, and review of the resulting proof before it is published in its final form. Please note that during the production process errors may be discovered which could affect the content, and all legal disclaimers that apply to the journal pertain. 
West Nile 13.09.2010 eveline.wodak@ages.at

Detection and molecular analysis of West Nile virus infections in birds of prey in the eastern part of Austria in 2008 and 2009

Eveline Wodak $^{\mathrm{a}, *}$, Susanne Richter ${ }^{\mathrm{a}}$, Zoltán. Bagó ${ }^{\mathrm{a}}$, Sandra Revilla-Fernández ${ }^{\mathrm{a}}$, Herbert

Weissenböck ${ }^{\mathrm{b}}$, Norbert Nowotny ${ }^{\mathrm{c}}$, Petra Winter ${ }^{\mathrm{a}}$

${ }^{a}$ Institute for Veterinary Disease Control Mödling, Austrian Agency for Health and Food Safety (AGES), Robert Koch-Gasse 17, 2340 Mödling, Austria

${ }^{\mathrm{b}}$ Institute of Pathology and Forensic Veterinary Medicine, Department of Pathobiology, University of Veterinary Medicine, Vienna, Veterinärplatz 1, 1210 Vienna, Austria ${ }^{c}$ Zoonoses and Emerging Infections Group, Clinical Virology, Department of Pathobiology, University of Veterinary Medicine, Vienna, Veterinärplatz 1, 1210 Vienna, Austria

*Corresponding author: Tel.: + 4350 555-38230; fax: +43 50 555-38309.

E-mail address: eveline.wodak@ages.at

Keywords: West Nile virus, Flavivirus, mosquito-borne flavivirus, zoonosis, goshawk, Austria 
West Nile 13.09.2010 eveline.wodak@ages.at

\section{Abstract}

3 The emergence of West Nile virus (WNV) was expected in Austria since the initial discovery

4 of the infection in neighbouring Hungary in 2003/2004. In 2008 six cases of West Nile

5 disease were diagnosed at the Institute for Veterinary Disease Control Mödling, Austrian

6 Agency for Health and Food Safety (AGES), involving five goshawks (Accipiter gentilis) and

7 one gyrfalcon (Falco rusticolus), which were found dead in the eastern Austrian federal states

8 of Lower Austria, Vienna and Styria, respectively. Pathomorphological and

9 immunohistochemical findings suggested a WNV infection. Virus was isolated in

embryonated specific pathogen free chicken eggs and propagated in mouse neuroblastoma

11 cells (NA), in which a cytopathic effect occurred. The virus was identified and characterised

12 by electron microscopic examination and molecular detection using RT-PCR, sequencing, and

13 phylogenetic analysis. The Austrian WNV sequences exhibited nucleotide identities of $99.9 \%$

14 to the lineage 2 WNV sequences described in Hungary since 2004. In addition, 71 sera of 14

15 different bird species were screened for the presence of WNV antibodies using a commercial

16 ELISA: $43,7 \%$ of the tested samples showed antibody titres. Selected positive sera were also

17 subjected to WNV neutralisation tests, in which the ELISA results were verified in $66 \%$. The

18 results of this study confirm unambiguously the presence of a lineage $2 \mathrm{WNV}$ infection in

19 birds of prey in the eastern part of Austria. 
West Nile 13.09.2010 eveline.wodak@ages.at

\section{Introduction}

West Nile virus (WNV; family Flaviviridae; genus Flavivirus) is a member of the Japanese encephalitis virus group within the mosquito-borne flaviviruses. The Japanese encephalitis antigenic complex of viruses includes Cacipacore virus (CPCV), Koutango virus (KOUV), Japanese encephalitis virus (JEV), Murray Valley encephalitis virus (MVEV), Alfuy virus (ALFV), St. Louis encephalitis virus (SLEV), Usutu virus (USUV), Yaounde virus (YAOV) and Kunjin virus (KUNV, which actually represents lineage 1b of WNV) (Thiel et al., 2005). WNV was first identified in Africa in 1937 (Smithburn et al., 1940) and subsequently, was detected in Europe, Asia, Australia, the American Continent and the Caribbean (Trevejo and Eidson, 2008). It has been proposed that one of the reasons for the rapid expansion is the high mobility of the virus in avian reservoirs (Malkinson and Banet, 2002; Rappole and Hubálek, 2003). A broad host and vector range was demonstrated for WNV (Balenghien et al., 2008), since it had been detected in at least 317 avian and 62 mosquito species (CDC). This virus is transmitted particularly by ornithophilic mosquitoes of the genus Culex within the bird populations, but some mosquito species are also capable of transmitting the virus to mammals such as horses, sheep or humans (Linke et al., 2007).

WNV has been present in Europe since decades (Hubálek and Halouzka, 1999). However, disease outbreaks were limited in time and geographic range, and presented as neurological disease in human beings or equines (Hubálek and Halouzka, 1999; Cantile et al., 2000; Krisztalovics et al., 2008). WNV-outbreaks affecting humans and horses are currently (since early August 2010) going on in Northern Greece (Website: Hellenic Centre for Disease Control and Prevention; Doudounakis, 2010). Starting in 2003, episodes of WNV-associated deaths in a flock of domestic geese and wild bird mortality have been reported from Hungary (Bakonyi et al., 2006; Erdélyi et al., 2007). The WNV strain involved in the goose outbreak in 2003 belonged to lineage 1, whereas wild bird mortality was due to a lineage 2 strain, which was for the first time identified in a goshawk in a national park in southeastern Hungary in 
West Nile 13.09.2010 eveline.wodak@ages.at

2004 (Bakonyi et al., 2006). In Austria, West Nile disease was never observed, only

seroconversion to WNV had been detected in different animal species in the sixties and seventies of the last century (Aspöck et al., 1973; Grešikova et al., 1973, for review see

Weissenböck et al., 2010). Attempts to identify WNV infections in equines and birds had been unsuccessful until summer 2008 (Nowotny, 2010).

The objective of this study was to describe a WNV outbreak in birds of prey in 2008 and 2009 in the eastern part of Austria.

\section{Materials and Methods}

\section{Study site and sample collection}

In mid-August 2008, a wild dead goshawk (Accipiter gentilis) was submitted to the Institute for Veterinary Disease Control Mödling for post-mortem examination with the anamnesis of sudden death after showing deviant behaviour caused by neurological symptoms. A WNV neuroinvasive infection was presumed. The same tentative diagnosis was proposed one week later for two additionally submitted goshawks, showing similar symptoms. In the same year, also one out of ten dead gyrfalcons (Falco rusticolus) kept by a falconer in Vienna was submitted for examination. In summer 2009, two goshawks from different locations were submitted: one out of five dead goshawks from the east of St Pölten (Ollersbach), federal state of Lower Austria, and one goshawk from the east of Styria. Besides specific analyses for WNV routine testing for Avian Influenza and Paramyxovirus infections by real-time RTPCRs were carried out.

\section{Pathomorphological and immunohistochemical analyses}

All six carcasses - five goshawks and one gyrfalcon - were subjected to post-mortem examination including necropsy and histological analyses. For histological examination,

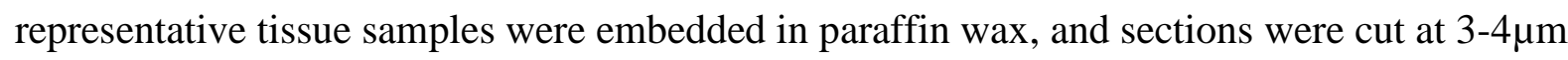
and stained with haematoxylin and eosin. Immunohistochemical staining for the detection of 
West Nile 13.09.2010 eveline.wodak@ages.at

WNV-antigen was performed using an avidin-biotin complex (ABC) detection system according to the manufacturers instructions. The primary antibody was a polyclonal antiWNV mouse serum (dilution: 1:2500; kindly provided by Dr. B. Murgue, Institut Pasteur, Paris), which has been previously shown to efficiently detect WNV antigen in positive control tissues (Weissenböck et al., 2003).

\section{Molecular analysis}

Viral RNA was isolated with the RNeasy ${ }^{\circledR}$ Kit (Qiagen, Vienna, Austria) from a pool of selected tissues including brain, spleen, lung, liver, intestine and trachea. Initial WNVspecific analysis was performed using a modification of the method published by Linke et al. (2007) with $5 \mu 1$ RNA and the SuperScript IIITM Platinum ${ }^{\circledR}$ One-Step Quantitative RT-PCR System (Invitrogen). For verification, a RT-PCR, based in the conserved NS5 region, which is able to detect all members of the Japanese encephalitis virus antigenic group of flaviviruses (Weissenböck et al., 2002) was applied. This RT-PCR was performed with the SuperScript IIITM Platinum ${ }^{\circledR}$ RT-PCR System (Invitrogen) by using $5 \mu$ RNA and 500nM of each primer in a $25 \mu 1$ total reaction volume. The PCR products were analysed by electrophoresis on a $1.5 \%$ agarose gel and DNA was purified with the QIAquick® Gel Extraction kit (Qiagen). Sequencing reaction was prepared with the Big Dye® Terminator v3.1 kit (Applied Biosystems), and analysed in a 3130xl Genetic Analyzer (Applied Biosystems). WNV NS5 partial sequences of $897 \mathrm{bp}$ were aligned using the Bionumerics software v6.0 (Applied Maths, Sint-Martens-Latem, Belgium). In order to investigate the genetic relationship of the Austrian WNV samples to representative other WNV strains, a phylogenetic tree was constructed by UPGMA analysis. WNV strains published in the NCBI GenBank representing lineages 1,2, putative lineages 3, 4 and 5, and Usutu Virus strains as outgroup were included. Recent WNV strains characterised in humans and animals, and those isolated from birds in Hungary (Bakonyi et al., 2006), Italy (Barzon et al., 2009), France and Spain (Sotelo et al., 2009) were primarily considered. 
West Nile 13.09.2010 eveline.wodak@ages.at

\section{Virus isolation}

Virus isolation attempts were carried out using a pool of brain, liver, intestine and lung tissues in embryonated specific pathogen free chicken eggs (SPFE) (Lohmann, Cuxhaven, Germany) according to the OIE Manual of Diagnostic Tests and Vaccines for Terrestrial Animals. The chorioallantoic fluid was harvested, analysed for WNV particles by electron microscopy, and used for further virus propagation in mouse neuroblastoma (NA) cell cultures. The cells were incubated in Eagle's MEM supplemented with 1\% l-glutamine, $1 \%$ non-essential amino acids, $1 \%$ of $100 \mathrm{mM}$ sodium pyruvate, $158 \mu \mathrm{g} / \mathrm{ml}$ neomycin, $80 \mu \mathrm{g} / \mathrm{ml}$ bacitracin and fetal calf serum to reach a final concentration of $10 \%$. Cell cultures were incubated at $37^{\circ} \mathrm{C}$ and $5 \%$ $\mathrm{CO}_{2}$ and examined daily for evidence of viral cytopathic effect (CPE). Cell culture isolates were subjected to real-time RT-PCR (RT-qPCR) and sequence analysis.

\section{Serological tests}

Seventy-one sera of fourteen different avian species were screened for the presence of WNV antibodies (Table 2). Samples were collected from birds close to the location of the first goshawk infections as well as from aviaries at the Research Institute of Wildlife Ecology, University of Veterinary Medicine, Vienna. Antibodies to WNV were tested by EnzymeLinked ImmunoSorbent Assay (ELISA) using the ID Screen ${ }^{\circledR}$ West Nile Competition Screening test (ID VET, Montpellier, France) according to the manufacturer's instructions. When sufficient material was available, sera with positive or borderline ELISA results were also tested by WNV neutralisation test, which was established as an in-house method. The neutralisation test was performed in a 96-well plate format with Eagle's MEM, supplemented with $1 \%$ l-glutamine, 5\% Fungizone and $10 \%$ fetal calf serum. Sera were inactivated for $30 \mathrm{~min}$ at $56^{\circ} \mathrm{C}$. Serum samples were diluted in a $50 \mu 1$ system in two-fold steps, starting with a dilution of $1: 10$ to $1: 1280$. The $100 \mathrm{TCID}_{50}$ titer of the stock solution (WNV isolate of the goshawk, case 1) was $10^{-3.3}$ in $50 \mu 1.50 \mu 1$ of the stock solution was added to each well except the wells of the cell control. All samples were incubated for one hour at $37^{\circ} \mathrm{C}$. NA cells were 
West Nile 13.09.2010 eveline.wodak@ages.at

124

125

126

127

128

129

130

131

132

133

134

135

136

137

138

139

140

141

142

143

grown as described for virus isolation (OIE Manual 2008, Chapter 2.01.13.B.1.ii). After incubation, the cells were added and further incubated at $37^{\circ} \mathrm{C}$ in an atmosphere of $5 \% \mathrm{CO}_{2}$. All samples were run in duplicate. Sera were considered positive after similar antibody titers in two test runs. The test serum results are expressed as the reciprocal of the dilution of serum that neutralised the virus in $50 \%$ of the wells. The start dilution of the serum samples was $1: 10$. If $50 \%$ of the wells with $1 / 10$ diluted serum neutralised the virus, the titre is 10 . For qualitative results, any neutralisation at a titre of 10 or above is considered to be positive.

\section{Electron microscopic examinations}

For negative staining, spleen, pancreas, cerebrum, cerebellum, and mesencephalon of goshawks and the embryos of the infected egg cultures were grounded in sodium phosphate buffer (1 part tissue : 10 parts buffer), and further processed by UV irradiation, immersion in Alcian Blue and ultracentrifugation. The supernatants of the centrifuged $\left(4^{\circ} \mathrm{C}, 1300 \mathrm{~g}\right.$ for 15min) suspensions were ultracentrifuged with a Beckman Airfuge for $15 \mathrm{~min}$ (91124 x g at 20psi) on carbon coated Pioloform copper grids. Grids were stained with $0.5 \%$ aqueous uranyl acetate and $0.5 \%$ aqueous phosphotungstic acid. The same procedure was performed with allantoic fluid and cell culture supernatant. For analysis of ultrathin sections the above mentioned organs of the carcasses, organs (spleen, brain, heart) of the embryos and the cells from the inoculated NA cell cultures were fixed by immersion in cold Karnovsky solution $\left(4^{\circ} \mathrm{C}, \mathrm{pH} 7.3\right)$, post-fixed with cold phosphate buffered osmium tetroxide, embedded in Epon and polymerised at $60^{\circ} \mathrm{C}$ during 2 days. Infected cell cultures were investigated for flavivirus assembly after 18, 24 and 48h post inoculation. Semithin sections of $0.5 \mu \mathrm{m}$ thickness were stained with Richardson's solution, the 70nm thick ultrathin sections with methanolic uranyl acetate and lead citrate. All samples were analysed in a TEM (Zeiss 906) at 80kv.

\section{Results}

\section{Pathomorphological findings}


West Nile 13.09.2010 eveline.wodak@ages.at

150

151

152

153

154

155

156

157

158

159

160

161

162

163

164

165

166

167

168

169

170

171

172

173

174

175

The nutritional status of the 6 carcasses (two male, three female goshawks and one female gyrfalcon) was appropriate. An overview about the pathomorphological findings is given in

Table 1. Gross pathology revealed no specific findings except for a mild hepato- and splenomegaly as well as moderate meningeal haemorrhages of the cerebellum in case 3 .

Histological, the most striking feature in all cases was a moderate multifocal to diffuse nonpurulent meningoencephalitis with slight lymphocytic meningeal and perivascular infiltrates and formation of glial nodules (Fig. 2).

Varying amounts of viral antigen could be demonstrated by means of immunohistochemistry in the brain (neurons and their processes), spleen (histiocytes, dendritic cells, cells of the capsule), liver (hepatocytes, von Kupffer cells, intravascular mononuclear cells), eye (Str. nervosum retinae), heart (myocardial cells), kidney (tubular epithelial cells) and in some vegetative neurons of abdominal ganglia and the small intestine (Fig. 3 and Table 1). WNV antigen was also detected in the brain and the heart in one chicken embryo investigated immunohistochemically after death during the virus isolation trial.

\section{RT-qPCR, RT-PCR, sequencing and phylogenetical analysis of NS5 sequences}

The five goshawks and the gyrfalcon were tested positive by RT-PCR for WNV. The WNV real-time RT-PCR revealed higher virus load in the organ pool of the first bird (quantification cycle $(\mathrm{Cq})$ value of 13.1$)$ compared to the single organ samples spleen and brain $(\mathrm{Cq}$ values around 15), whereas the $\mathrm{Cq}$ values obtained for the organ pool samples of the other five birds varied between 20.2 and 33.8 in the different samples.

The nucleotide sequences of the 1084bp long specific PCR product of the partial NS5 of the six Austrian WNV isolates analysed in this study were very similar. Pairwise alignment revealed one mismatch position (99.88\% identity) between the first goshawk (AT_763/08) and the other five bird cases, which were completely identical at the nucleotide level. As expected, the highest sequence homology $(99.77 \%)$ was found to WNV strains of lineage 2 detected in birds of prey in Hungary, i.e. strains Hu/04 and Hu/05 (DQ116961-goshawk and 
West Nile 13.09.2010 eveline.wodak@ages.at

176

177

178

179

180

181

182

183

184

185

186

187

188

189

190

191

192

193

194

195

196

197

198

199

200

EF116943-sparrow-hawk), respectively. According to our analysis, Austrian and Hungarian WNV strains as well as isolates from Central and South Africa belong to the same sub-cluster (Fig. 4). Neither WNV strain of the lineage 1, found in Italy in 2008 and 2009, nor the putative lineage 3 isolated in 1997 in Czech Republic (Bakonyi et al., 2005; Bakonyi et al., 2006) could be detected.

The NS5 partial sequences of the WNV strains detected in Austria were submitted to the

GenBank of the National Centre for Biotechnology Information (NCBI) under the following accession numbers: GU566737-GU566740 and HM015884 for the 5 goshawk cases and

GU580891 for the gyrfalcon. Further alignment with other representative WNV sequences of different lineages and two Usutu virus strains published by the NCBI GenBank (Fig. 4) was carried out.

\section{Virus isolation}

During the first passage of samples in SPFE, one chicken embryo died on third, fourth and fifth day of incubation. Two chicken embryos per day died on the fourth, fifth and sixth day of incubation of second passage. Three days after inoculation with CAF from the inoculated SPFE a general CPE in the NA cell culture was seen. The CPE was characterized by the appearance of rounded, refractile cells followed by complete destruction of the cell monolayer.

\section{ELISA and Virus Neutralisation Test}

Serological results are summarised in Table 2.

From the 71 serum samples tested; 31 samples $(43,7 \%$ of the living birds) showed a positive reaction in the ELISA, which seemed to be not only specific for WNV as mentioned by the manufacturers. Positive reactions were found in two chickens (Gallus gallus domesticus), two graylag goose (Anser anser), ten bearded vultures (Gypaëtus barbatus), twelve Ural owls (Strix uralensis), one common buzzard (Buteo buteo), two golden eagles (Aquila chrysaëtos), 
West Nile 13.09.2010 eveline.wodak@ages.at

and two goshawks (Accipiter gentilis). 66\% of the positive ELISA reactions could be confirmed in the NT (see Table 2).

\section{Electron microscopic examinations}

Virions were found in negative staining in the suspension of organ tissue of goshawks, in the allantoic fluid and brain tissue of infected chicken embryos (45-55nm in diameter). Virions were enveloped, icosahedral in shape and resembled structurally viruses of the family Flaviviridae (Fig. 5a).

In ultrathin sections prepared from tissue of infected goshawks, flavivirus particles were frequently seen in the cerebellum, liver, exocrine pancreas and spleen, which exhibited multiple small foci of necrotic apoptotic lymphoid cells and deposition of fibrin.

Virus particles detected in the bird organs measured about $50 \mathrm{~nm}$ in diameter and showed typical flaviviral morphology, that is, a dense, round core surrounded by a thin, diffuse outer layer. Viruses were often found solely in tissue cells, especially in pancreatic acinar cells (Fig. 5c). Packages of viruses, especially in cytoplasmic vacuoles, were rarely seen, however, most frequently detected in hepatocytes (Fig. 5d) and perikarya or neuronal processes of brain tissue (Fig. 5b). Viral accumulations were also rare in heart, brain and splenic tissue of infected embryos.

Neuroblastoma cells (Fig. 6a-c), investigated after 18 and 24 hours, revealed a complex of vesicular membrane structures of 80-100 nm diameters. Virus particles were observed within the lumen of these membrane cisternae which were part of the endoplasmatic reticulum (ER) and Golgi network (Fig. 6b-insertion). In autolytic neuroblastoma cells (48h post infection) virions were accumulated in large vesicles (Fig. 6c).

\section{Discussion}

Virus isolation and serological tests proved the virus nature of the pathogen. Electron microscopic analysis revealed flavivirus infection in several organs of goshawks. Analysis of 
West Nile 13.09.2010 eveline.wodak@ages.at

227

228

229

230

virus infected neuroblastema cell culture showed membrane structures identical to vesicular packets found in connection with Dengue virus- and Kunjin virus-replication (Mackenzie and Westaway, 2001; Welsch et al. 2009). The pathomorphological and immunohistochemical findings agree with the report of lineage $2 \mathrm{WNV}$ cases in goshawks from Hungary (Erdélyi et al., 2007). Molecular biological diagnostics confirmed the infection of WNV lineage 2, and sequence analysis showed $99.77 \%$ homology to the Hungarian isolates. High identity to the Hungarian lineage 2 West Nile virus strain was also obtained from the West Nile viruses detected in a pool of Culex_mosquitoes collected in Greece (Papa, 2010). In Austria, WNV lineage 2 was the causative agent of the observed clinical signs and the death of the birds. Fortunately, in Austria, compared to other European countries like Italy, Hungary and Greece (Kecskeméti et al., 2007; Rizzo et al., 2009; Doudounakis, 2010), no transmission to mammals like horses, sheep and humans were reported by now and the infection seems to be limited to birds of prey.

The pathological lesions and the virus distribution of the present WNV lineage 2 infections largely resemble the observation from cases of lineage $1 \mathrm{WNV}$ infections from North America (Steele et al., 2000; Wünschmann et al., 2005). Here the circulating strain caused a hitherto unprecedented epornithic with selective vulnerability of certain bird species, e.g. the American crow (Corvus brachyrhynchus). In this bird species a significantly enhanced virulence has been demonstrated experimentally (Komar et al., 2003), which has been recently associated with a point mutation resulting in an amino acid change in the NS3 protein of the North American WNV strain (Brault et al., 2007). The selective vulnerability of birds of prey for the lineage 2 virus circulating in Central Europe is obvious and suggests an underlying similar molecular mechanism, which is still unknown. It also showed that birds of prey, and particularly goshawks, seem to be a biological indicator for the activity of the WNV lineage 2 in Austria. 
West Nile 13.09.2010 eveline.wodak@ages.at

252

253

254

255

The recent clinical findings of WNV infections in goshawk and gyrfalcon not far from the eastern border of Austria to Hungary (Bakonyi et al., 2006) demonstrated that an introduction of this virus into Austria was only a question of time. The same WNV strain detected in 2008 in the south of Vienna was identified one year later in a goshawk showing clinical symptoms in Ollersbach / St. Pölten (federal state of Lower Austria) and in another goshawk at the eastern part of Styria (district of Weiz), indicating an expansion of the area of WNV activity to the west and south. It is not possible to trace exactly the introduction routes of WNV to the Austrian bird of prey population. To our knowledge there have been no reports on WNV detection in birds or other animals in Austria before, only seroconversion was demonstrated in a few horses imported from Eastern Europe (Weissenböck et al., 2003; Weissenböck et al., 2010). Birds are the natural reservoir of the virus, and migratory birds are playing probably a major role in introduction or re-introduction of the virus in a given area. The majority of WNV transmission between birds occurs through mosquito bites. However, transmission through faeces (Kipp et al., 2006) as well as oral transmission should not be discounted and suggestions for this route of transmission have been found in birds of prey in Spain, Hungary, Israel and North America (ECDC). As a consequence of the introduction of WNV to Austria, surveillance programs, which have been considered an effective tool in early detecting of new emerging bird diseases like Avian Influenza, have been promptly established based on virus detection in wild birds with special attention to birds of prey (Falconiformes) and Passeriformes (crows and raven) in Lower Austria and Burgenland, respectively. Serological screenings of birds in the areas at risk will also give an overview about the epidemic situation. It is likely that WNV is becoming a permanently established pathogen with the tendency to disperse, at least in the eastern (and possibly south-eastern) part of Austria, since the same virus strain has been detected in two consecutive years. Transmission by mosquito vectors plays a major role in WNV epidemiology. Hence, when mosquito-borne pathogens have been introduced to a certain area, transmission can be sustained provided suitable vectors are 
West Nile 13.09.2010 eveline.wodak@ages.at

present. Potential vectors of WNV, especially Culex sp. and Aedes sp., belong to the most prevalent mosquito species in Austria. A key parameter for a permanent residence or even further spread of the disease, in the context of climate change, is the extended chance of the pathogen to circulate between vectors and hosts (De la Rocque et al., 2008, Morand and Guéguan, 2008, Reiter, 2008). As future climatic conditions (Stone, 2008) and vector populations seem to be ideal for the establishment of newly introduced mosquito-borne diseases in Austria, West Nile fever will presumably become a permanent disease in our region, as the introduction of the related flavivirus Usutu virus to eastern Austria resulted in permanent residence of the virus in this area (Weissenböck et al., 2002, Weissenböck et al., 2003, Weissenböck et al., 2010). Furthermore, in the eastern part of Austria the climatic conditions are comparable to western Hungary, where WNV also established itself as resident pathogen with continuous dispersal into new areas (Bakonyi et al., 2006).

\section{Acknowledgments}

We are grateful to Helga Plicka, Christine Glatzer and the laboratory staff for technical assistance. We would also like to thank to Dr. Walter Gnigler, who reported the clinical infections of the goshawks and the gyrfalcon to the Institute.

\section{References}

Aspöck, H., Kunz, C., Picher, O., Böck, F., 1973. Virologische und serologische Untersuchungen über die Rolle von Vögeln als Wirte von Arboviren in Österreich. Zentralblatt für Bakteriologie A224, 156-167.

Bakonyi, T., Gould, E. A., Kolodziejek, J., Weissenböck, H., Nowotny, N. (2004). Complete genome analysis and molecular characterization of Usutu virus that emerged 
West Nile 13.09.2010 eveline.wodak@ages.at

in Austria in 2001: comparison with the South African strain SAAR-1776 and other flaviviruses. Virology 328, 301-310.

Bakonyi, T., Hubálek, Z., Rudolf, I., Nowotny, N., 2005. Novel flavivirus or new lineage of West Nile virus, central Europe. Emerg Infect Dis. 2005; 11, 225-231

Bakonyi, T., Ivanics, E., Erdélyi, K., Ursu, K., Ferenczi, E., Weissenböck, H., Nowotny, N., 2006. Lineage 1 and 2 strains of encephalitic West Nile virus, central Europe. Emerg. Infect. Dis. 12, 618-623.

Balenghien, T., Vazeille, M., Grandadam, M., Schaffner, F., Zeller, H., Reiter, P., Sabatier, P., Fouque, F., Bicout, D. J., 2008. Vector competence of some French Culex and Aedes mosquitoes for West Nile virus. Vector-Borne and Zoonotic Diseases 8, $589-595$.

Barzon, L., Franchin, E., Squarzon, L., Lavezzo, E., Toppo, S., Martello, T., Bressan, S., Pagni, S., Cattai, M., Piazza, A., Pacenti, M., Cusinato, R., Palù, G., 2009. Genome sequence analysis of the first human West Nile virus isolated in Italy in 2009. Eurosurveill. 14, 19384.

Bertelsen, M. F., Olberg, R.-A., Crawshaw, G. J., Dibernardo, A., Lindsay, L. R., Drebot, M., Barker, J. K., 2004. West Nile Virus infection in the eastern loggerhead shrike (Lanius ludovicianus migrans): Pathology, epidemiology, and immunization. J. Wildlife Dis., 40, 538-542.

Brault, A. C., Huang, C. Y., Langevin, S. A., Kinney, R. M., Bowen, R .A., Ramey, W. N., Panella, N. A., Holmes, E. C., Powers, A. M., Miller, B. R. 2007. A Single positively selected West Nile viral mutation confers increased virogenesis in American crows. Nat. Genet. 39, 1162-1166. 
West Nile 13.09.2010 eveline.wodak@ages.at

Bright, P. R., Turell, M. J., 2007. DNA vaccination of the American crow (Corvus brachyrhynchos) provides partial protection against lethal challenge with West Nile virus. Avian Dis. 51, 573-577.

Cantile, C., Di Guardo, G., Eleni, C., Arispici, M., 2000. Clinical and neuropathological features of West Nile virus equine encephalomyelitis in Italy. Equine Vet. J. 32, 31-35. CDC - http://www.cdc.gov/ncidod/dvbid/westnile/birdspecies.htm the endangered California condors (Gymnogyps californianus) protects this species from lethal West Nile virus infection. Vaccine 25, 2325-2330.

De la Rocque, S., Rioux, J. A., Slingenbergh, J., 2008. Climate change: effects on animal disease systems and implications for surveillance and control. Rev. sci. tech. Off. int. Epiz. 27, 339-354.

Doudounakis, Sp., 2010. ProMED-mail archive no. 20100828.3058, 28. Aug. 2010

ECDC, 2009. Expert Consultation on West Nile infection - Meeting Report Stockholm 21-22. April 2010, http://www.ecdc.europa.eu/en/publications/Publications/0909_MER_Expert_consultat ion_on_WNV.pdf Haemagglutination-inhibiting antibodies against arboviruses in human sera from different regions in Steiermark (Austria). Zentralblatt für Bakteriologie 224, 298-302. disease in Europe. Emerg. Infect. Dis. 5, 643-650. 
West Nile 13.09.2010 eveline.wodak@ages.at

Karaca, K., Bowen, R., Austgen, L.E., Teehee, M., Siger, L., Grosenbaugh, D., Loosemore, L., Audonnet, J.-C., Nordgren, R., Minke, J. M., 2005. Recombinant canarypox vectored West Nile virus (WNV) vaccine protects dogs and cats against a mosquito WNV challenge. Vaccine 23, 3808-3813.

Kecskeméti, S., Bajmócy, E., Bacsadi, A., Kiss, I., Bakonyi, T., 2007. Encephalitis due to West Nile virus in a sheep. Vet. Rec. 161, 568-569.

Kipp, A. M., Lehmann, J. A., Bowen, R. A., Fox, P. E., Stephens, M. R., Klenk, K., Komar, N., Bunning, M. L., 2006. West Nile Virus quantification in faeces of experimentally infected American and fish crows. Am. J. Trop. Med. Hyg. 75, 688690.

Komar, N., Langevin, S., Hinten, S., Nemeth, N., Edwards, E., Hettler, D., Davis, B., Bowen, R., Bunning, M., 2003. Experimental infection of North American birds with the New York 1999 strain of West Nile virus. Emerg. Infect. Dis. 9, 311-322.

Krisztalovics, K., Ferenczi, E., Molnár, Zs., Csohán, Á., Bán, E., Zöldi, V., Kaszás, K., 2008. West Nile virus infections in Hungary, August-September 2008. Eurosurveill. $13,1-3$.

Linke, S., Niedrig, M., Kaiser, A., Ellerbrok, H., Müller, K., Müller, T., Conraths, F. J., Mühle, R. U., Schmidt, D., Köppen, U., Bairlein, F., Berthold, P., Pauli, G., 2007. Serologic evidence of West Nile virus infections in wild birds captured in Germany. Am. J. Trop. Med. Hyg. 77, 358-364.

Mackenzie, J. M., Westaway, E. G., 2001. Assembly and maturation of the flavivirus Kunjin virus appear to occur in the rough endoplasmatic reticulum and along the secretors pathway, respectively. J. Virol. 75, 10787-10799.

Malkinson, M., Banet, C., 2002. The role of birds in the ecology of West Nile virus in Europe and Africa. Curr. Top. Microbiol. Immunol. 267, 309-322. 
West Nile 13.09.2010 eveline.wodak@ages.at

Morand, S., Guéguan, J.-F., 2008. How the biodiversity sciences may aid biological tools and ecological engineering to assess the impact of climate changes. Rev. sci. tech. Off. int. Epiz. 27, 355-366.

Nowotny, N., (2010). ProMED-mail archive no. 20100914.3312, 14 Sept. 2010

OIE, 2009. Manual of diagnostic tests and vaccines for terrestrial animals, 5th edn. Office Internationale des Epizooties, Paris, France, http://www.oie.int/fr/normes/mmanual/A_summry.htm

Papa, A., 2010. ProMED-mail archive no. 20100816.2843, 16 Aug. 2010

Rappole, J. H., Hubálek, Z., 2003. Migratory birds and West Nile virus. J. Appl. Microbiol. 94 Suppl., 47S-58S.

Reiter, P., 2008. Climate change and mosquito-borne disease: knowing the horse before hitching the car. Rev. sci. tech. Off. int. Epiz. 27, 383-398.

Rizzo, C., Vescio, F., Declich, S., Finarelli, A.C., Macini, P., Mattivi, A., Rossini, G., Piovesan, C., Barzon, L., Palu, G., Gobbi, F., Macchi, L., Pavan, A., Magurano, F., Ciufolini, M.G., Nicoletti, L., Salmaso, S., Rezza, G., 2009. West Nile virus transmission with human cases in Italy, August - September 2009. Euro Surveill. 14(40):pii=19353. Available online: <http://www.eurosurveillance.org/ViewArticle.aspx?ArticleId=19353>.

Smithburn, K. C., Hughes, T. P., Burke, A.W., Paul, J. H., 1940. A neurotropic virus, isolated from the blood of a native of Uganda. Am. J. Trop. Med. Hyg. 20, 471-492.

Sotelo, E., Fernandez-Pinero, J., Llorente, F., Agüero, M., Hoefle, U., Blanco, J. M., Jiménez-Clavero, M. A., 2009. Characterization of West Nile virus isolates from Spain: new insights into the distinct West Nile virus eco-epidemiology in the Western Mediterranean. Virology. 395, 289-297. 
West Nile 13.09.2010 eveline.wodak@ages.at

401

402

403

404

405

406

407

408

409

410

411

412

413

414

415

416

417

418

419

420

421

422

423

Steele, K. E., Linn, M. J., Schoepp, R. J., Komar, N., Geisbert, T. W., Manduca, R. M., Calle, P. P., Raphael, B. L., Clippinger, T. L., Larsen, T., Smith, J., Lanciotti, R. S., Panella, N. A., McNamara, T. S., 2000. Pathology of fatal West Nile virus infections in native and exotic birds during the 1999 outbreak in New York City, New York. Vet. Pathol. 37, 208-224.

Stone, D. A., 2008. Predicted climate changes for the years to come and implications for disease impact studies. Rev. sci. tech. Off. int. Epiz. 27, 319-330.

Thiel, H. J., Collett, M. S., Gould, E. A., Heinz, F. X., Meyers, G., Purcell, R. H., Rice, C. v. M., Houghton, M., 2005. Flaviviridae. In: Fauquet, C. M., Mayo, M. A., Maniloff, J., Desselberger, U., Ball, L. A. (Eds.), Virus Taxonomy, eighth report of the international committee on taxonomy of viruses. Elsevier Academic Press, San Diego, London, pp. 981-998.

Trevejo, R. T., Eidson, M., 2008. Zoonosis update: West Nile virus. J. Am. Vet. Med. Assoc. 232, 1302-1309.

Weissenböck, H., Hubálek, Z., Bakonyi, T., Nowotny, N., 2010. Zoonotic mosquito-borne flaviviruses: Worldwide presence of agents with proven pathogenicity and potential candidates of future emerging diseases. Vet. Microbiol. 144, 271-280.

Weissenböck, H., Hubálek, Z., Halouzka, J., Pichlmair, A., Maderner, A., Fragner, K., Kolodziejek, J., Loupal, G., Kölbl, S., Nowotny, N., 2003. Screening for West Nile virus infections of susceptible animal species in Austria. Epidemiol. Infect. 31, 10231027.

Weissenböck, H., Kolodziejek, J., Fragner, K., Kuhn, R., Pfeffer, M., Nowotny, N. (2003). Usutu virus activity in Austria, 2001-2002. Microbes Infect. 5, 1132-1136. 
West Nile 13.09.2010 eveline.wodak@ages.at

Weissenböck, H., Kolodziejek, J., Url, A., Lussy, H., Rebel-Bauder, B., Nowotny, N., 2002. Emergence of Usutu virus, an African mosquito-borne flavivirus of the Japanese encephalitis virus group, central Europe. Emerg. Infect. Dis. 8, 652-656.

Welsch, S., Miller, S., Romero-Brey, I., Merz, A., Bleck, Ch. K. E., Walther, P., Filler, St. D., Antony, C., Krijnse-Locker, J., Bartenschlager, R., 2009. Composition and threedimensional architecture of the Dengue virus replication and assembly site. Cell Host \& Microbe 5, 365-375.

Wünschmann, A., Shivers, J., Bender, J., Carroll, L., Fuller, S., Saggese, M., Van Wettere, A., Redig, P., 2005. Pathologic and Immunohistochemical Findings in goshawks (Accipiter gentilis) and great horned owls (Bubo virginianus) naturally infected with West Nile virus. Avian Dis. 49, 252-259.

\section{Legends for Figures and Tables:}

Figure 1: Geographical locations of birds with lethal WNV infections

Figure 2: Goshawk, WNV-encephalitis, brain. Neuronal necroses surrounded by glial nodules. Microphoto, H\&E, bar $=25 \mu \mathrm{m}$.

Figure 3: Goshawk, WNV-encephalitis, brain. High amounts of WNV-antigen in neurons and their processes. Microphoto, $\mathrm{ABC}$-technique, $\mathrm{bar}=25 \mu \mathrm{m}$

Table 1: Pathomorphological findings and WNV antigen distribution in selected tissue samples.

Figure 4: Phylogenetic tree of partial NS5 sequences of recently found WNV isolates from lineage 1 (clades $1 \mathrm{a}$ and $1 \mathrm{~b}$ ), lineage 2 and the proposed putative lineages 3 and 4 , including 
West Nile 13.09.2010 eveline.wodak@ages.at

450

451

452

453

454

455

456

457

the WNV strains isolated in five goshawks and one falcon in Austria (GU566737-GU566740, HM015884 and GU580891), respectively. Branch lengths are proportional to the number of nucleotide changes (genetic distances). Scale bar shows the percentage of base substitutions in the sequence. The bootstrap analysis revealed that all WNV isolates from Austria are grouped within the lineage 2 with the Hungarian strains (not shown). Note: CF, Central African Republic.

Table 2: Prevalence of West Nile virus - neutralising antibodies among living birds, sampled in Lower Austria nearby finding place of the first WNV diseased goshawk and from aviaries at the Research Institute of Wildlife Ecology in Vienna. 38,7\% of the positive ELISAsamples (ID Screen ${ }^{\circledR}$ West Nile Competition Screening test) were subsequently checked by WNV neutralisation test.

Fig. 5: Accipiter gentilis (Goshawk): Negative staining: a) Flavivirus particles from spleen suspension. bar $=50 \mathrm{~nm}$; b-d) Epon sections of affected organs, arrows point to virus particles b) Cerebellum: virus particles in vacuoles of perikarya and neuronal processes (insert), bar = 100nm c) exocrine part of the pancreas: virus particles in cytoplasma (left insert) and between ER of acinar pancreatic cells (right insert), bar $=85 \mathrm{~nm} \mathrm{~d}$ ) liver: virus particles in vacuolar system of hepatocytes, bar $=100 \mathrm{~nm}$

Fig.6: Neuroblastoma cell: a) WNV 2-infected cell - after $18 \mathrm{~h}$ postinfection, bar $=1 \mu \mathrm{m}$; insert: dilated ER $-18 \mathrm{~h}$, bar $=100 \mathrm{~nm}$; b) vesicular membrane structure complex $(\mathrm{vm})$, autolytic body (a); insert: virus particle inside membrane cisterna $-24 \mathrm{~h}$, bar $=100 \mathrm{~nm} ; \mathrm{c}$ ) autolytic cell: accumulation of virions (arrow) in large vesicles $-48 \mathrm{~h}$, bar $=100 \mathrm{~nm}$ 
West Nile 13.09.2010 eveline.wodak@ages.at

Table 1:

\begin{tabular}{|c|c|c|c|c|c|c|c|c|c|c|c|c|}
\hline \multirow[b]{2}{*}{ Organ } & \multicolumn{2}{|c|}{$\begin{array}{c}\text { Case } 1 \\
\text { Accipiter } \\
\text { gentilis }\end{array}$} & \multicolumn{2}{|c|}{$\begin{array}{c}\text { Case } 2 \\
\text { A. gentilis }{ }^{\dagger}\end{array}$} & \multicolumn{2}{|c|}{$\begin{array}{c}\text { Case } 3 \\
\text { A. gentilis }{ }^{\dagger}\end{array}$} & \multicolumn{2}{|c|}{$\begin{array}{c}\text { Case } 4 \\
\text { Falco } \\
\text { rusticolus }{ }^{\dagger}\end{array}$} & \multicolumn{2}{|c|}{$\begin{array}{c}\text { Case } 5 \\
\text { A. gentilis } \dagger\end{array}$} & \multicolumn{2}{|c|}{$\begin{array}{c}\text { Case } 6 \\
\text { A. gentilis } \dagger\end{array}$} \\
\hline & PMF & IHC & PMF & IHC & PMF & IHC & PMF & IHC & PMF & IHC & PMF & IHC \\
\hline Brain & np. enc. & $*_{+++}$ & np. enc. & + & $\begin{array}{l}\text { np. enc., } \\
\text { men. haem. }\end{array}$ & +++ & np. enc. & ++ & np. enc. & +++ & np. enc. & ++ \\
\hline Spleen & $\begin{array}{l}\text { sm., } \\
\text { necr. }\end{array}$ & +++ & NT & NT & sm. & NT & NAD & + & sm., necr. & +++ & NAD & ++ \\
\hline Liver & $\begin{array}{l}\text { hm., } \\
\text { chst. } \\
\text { int. hep. }\end{array}$ & +++ & hm., chst. & - & hm., chst. & + & $\mathrm{hm}$. & + & int. hep. & & $\begin{array}{l}\text { hm. chst. } \\
\text { siderosis }\end{array}$ & ++ \\
\hline Heart & NAD & - & hp. & + & NAD & ++ & NAD & ++ & np. myoc. & + & $\begin{array}{l}\text { np. } \\
\text { myoc. }\end{array}$ & ++ \\
\hline Kidney & NAD & - & NAD & + & tn., tdil. & - & NAD & NT & $\begin{array}{l}\text { int. nep. \& } \\
\text { fibr., tdil. }\end{array}$ & + & NAD & NT \\
\hline Lung & NAD & - & anthracosis & - & $\begin{array}{l}\text { gn. pneum., } \\
\text { anthracosis }\end{array}$ & - & edema & NT & edema & - & NAD & NT \\
\hline Small i. & NAD & - & NAD & + & NAD & + & NAD & NT & NAD & + & $\begin{array}{l}\text { np. } \\
\text { gangl. }\end{array}$ & + \\
\hline Testes & NAD & NT & & & NAD & - & & & & & & \\
\hline Ovary & & & NAD & NT & & & NAD & NT & NAD & NT & NAD & NT \\
\hline Salpinx & & & NAD & - & & & NAD & NT & NAD & NT & NAD & NT \\
\hline Eye & NT & NT & np. iridoc. & - & NT & NT & NT & NT & $\begin{array}{l}\text { np. iridoc. } \\
\& \\
\text { chorioid. }\end{array}$ & ++ & NT & \\
\hline
\end{tabular}

$\#=$ wild bird, $\dagger=$ aviary, $*$ amounts of antigen: $+++=$ high, $++=$ moderate, $+=$ low, $-=$ no antigen detected, $\mathrm{NT}=$ not tested, grey field $=$ sex specific organ not existing

Abbreviations: $\mathrm{PMF}=$ pathomorphological findings, $\mathrm{IHC}=$ immunohistochemistry, $\mathrm{np}=$ non purulent, enc $=$ encephalitis, men. haem $=$ meningeal haemorrhages, $\mathrm{sm}=$ splenomegaly, necr $=$ necrosis, $\mathrm{NT}=$ not tested, NAD $=$ no abnormalities detected, $\mathrm{hm}=$ hepatomegaly, chst $=$ intrahepatic cholestasis, int $=$ interstitial, hep $=$ hepatitis, $\mathrm{hp}=$ hydropericardium, myoc $=$ myocarditis, $\mathrm{tn}=$ tubulonephrosis, fibr $=$ fibrosis, tdil $=$ dilatation of renal tubuli, nep $=$ nephritis, gn $=$ granulomatous-necrotizing, pneum $=$ pneumonia, small $\mathrm{i}=$ small intestine, gangl = intramural ganglionitis, irodoc $=$ iridocyclitis, chrorioid $=$ chorioiditis. 
West Nile 13.09.2010 eveline.wodak@ages.at

Table 2:

\begin{tabular}{|c|c|c|c|c|c|}
\hline Species & Locality & $\begin{array}{l}\text { No. bird } \\
\text { samples }\end{array}$ & Status & $\begin{array}{l}\text { ELISA } \\
\text { No. pos./No. neg. }\end{array}$ & $\begin{array}{l}\text { WNV-NT } \\
\text { No. pos./No. neg. }\end{array}$ \\
\hline $\begin{array}{l}\text { Gallus gallus } \\
\text { domesticus } \\
\text { (Chicken) }\end{array}$ & $\begin{array}{l}\text { Lower } \\
\text { Austria }\end{array}$ & 10 & free range & $2 / 8$ & $\begin{array}{c}\mathrm{n}^{*}=1 \\
1 / 0\end{array}$ \\
\hline $\begin{array}{l}\text { Anas platyrhynchos } \\
\text { domesticus } \\
\text { (Domesticated } \\
\text { Muscovy duck) }\end{array}$ & $\begin{array}{l}\text { Lower } \\
\text { Austria }\end{array}$ & 4 & free range & $0 / 4$ & - \\
\hline $\begin{array}{l}\text { Anser anser } \\
\text { (Greylag Goose) }\end{array}$ & $\begin{array}{l}\text { Lower } \\
\text { Austria }\end{array}$ & 2 & free range & $2 / 0$ & $\begin{array}{c}n=1 \\
0 / 1\end{array}$ \\
\hline $\begin{array}{l}\text { Columba livia } \\
\text { domestica } \\
\text { (Domestic pigeon) }\end{array}$ & $\begin{array}{l}\text { Lower } \\
\text { Austria }\end{array}$ & 13 & domesticated & $0 / 13$ & - \\
\hline $\begin{array}{l}\text { Corvus frugilegus } \\
\text { (Rook) }\end{array}$ & $\begin{array}{l}\text { Lower } \\
\text { Austria }\end{array}$ & 1 & wild & $0 / 1$ & - \\
\hline $\begin{array}{l}\text { Accipiter gentilis } \\
\text { (Goshawk) }\end{array}$ & $\begin{array}{l}\text { Lower } \\
\text { Austria } \\
\end{array}$ & 1 & wild & $0 / 1$ & - \\
\hline $\begin{array}{l}\text { Accipiter gentilis } \\
\text { (Goshawk) }\end{array}$ & $\begin{array}{l}\text { Lower } \\
\text { Austria }\end{array}$ & 2 & aviary & $1 / 1$ & $\begin{array}{c}\mathrm{n}=1 \\
1 / 0\end{array}$ \\
\hline $\begin{array}{l}\text { Accipiter gentilis } \\
\text { (Goshawk) }\end{array}$ & Vienna & 2 & aviary & $1 / 1$ & $\begin{array}{c}\mathrm{n}=1 \\
1 / 0\end{array}$ \\
\hline $\begin{array}{l}\text { Gypaëtus barbatus } \\
\text { (Bearded Vulture) }\end{array}$ & Vienna & 12 & aviary & $10 / 2$ & $\begin{array}{c}n=3 \\
2 / 1\end{array}$ \\
\hline $\begin{array}{l}\text { Buteo buteo } \\
\text { (Common Buzzard) }\end{array}$ & Vienna & 1 & aviary & $1 / 0$ & $\mathrm{NT}^{\#}$ \\
\hline $\begin{array}{l}\text { Aquila chrysaëtos } \\
\text { (Golden Eagle) }\end{array}$ & Vienna & 2 & aviary & $2 / 0$ & $\begin{array}{c}\mathrm{n}=1 \\
1 / 0\end{array}$ \\
\hline $\begin{array}{l}\text { Strix uralensis } \\
\text { (Ural Owl) }\end{array}$ & Vienna & 18 & aviary & $12 / 6$ & $\begin{array}{c}\mathrm{n}=4 \\
2 / 2\end{array}$ \\
\hline $\begin{array}{l}\text { Strix varia } \\
\text { (Barred Owl) }\end{array}$ & Vienna & 2 & aviary & $0 / 2$ & - \\
\hline $\begin{array}{l}\text { Aegolius funereus } \\
\text { (Tengmalm's Owl) }\end{array}$ & Vienna & 1 & aviary & $0 / 1$ & - \\
\hline
\end{tabular}

$*_{\mathrm{n}}=$ number of samples tested positive in the ELISA, NT ${ }^{\#}=$ not tested 


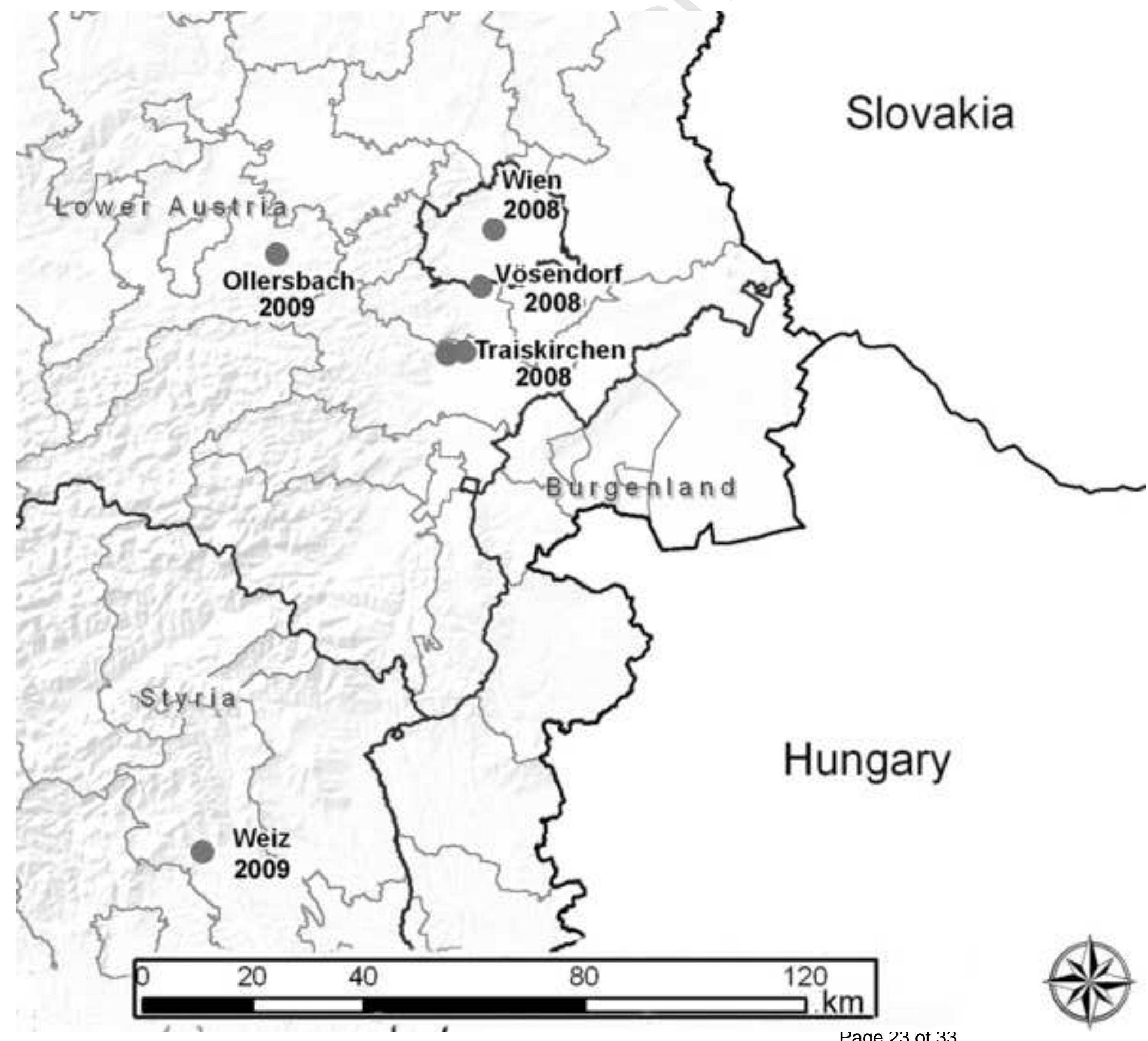


Click here to download high resolution image
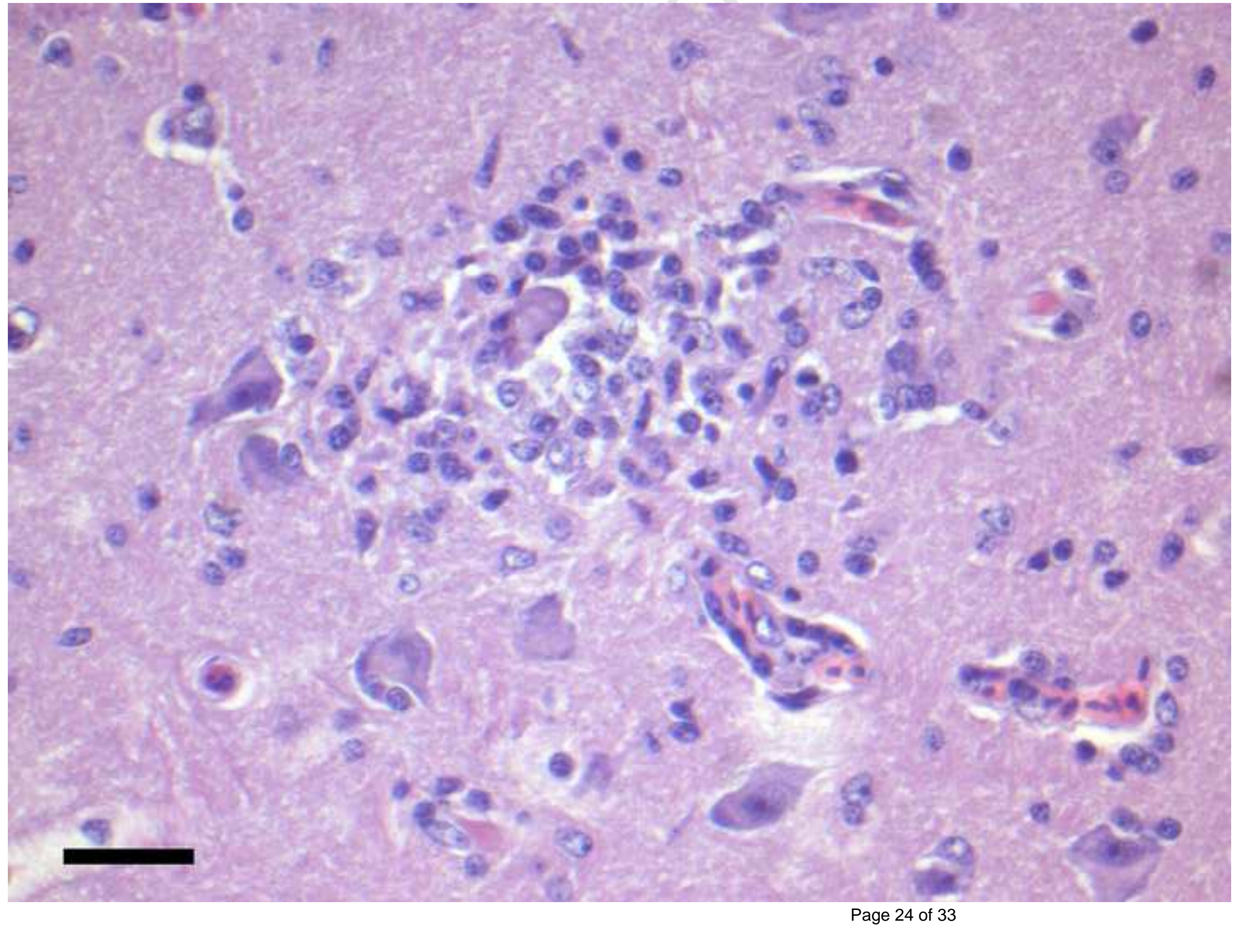


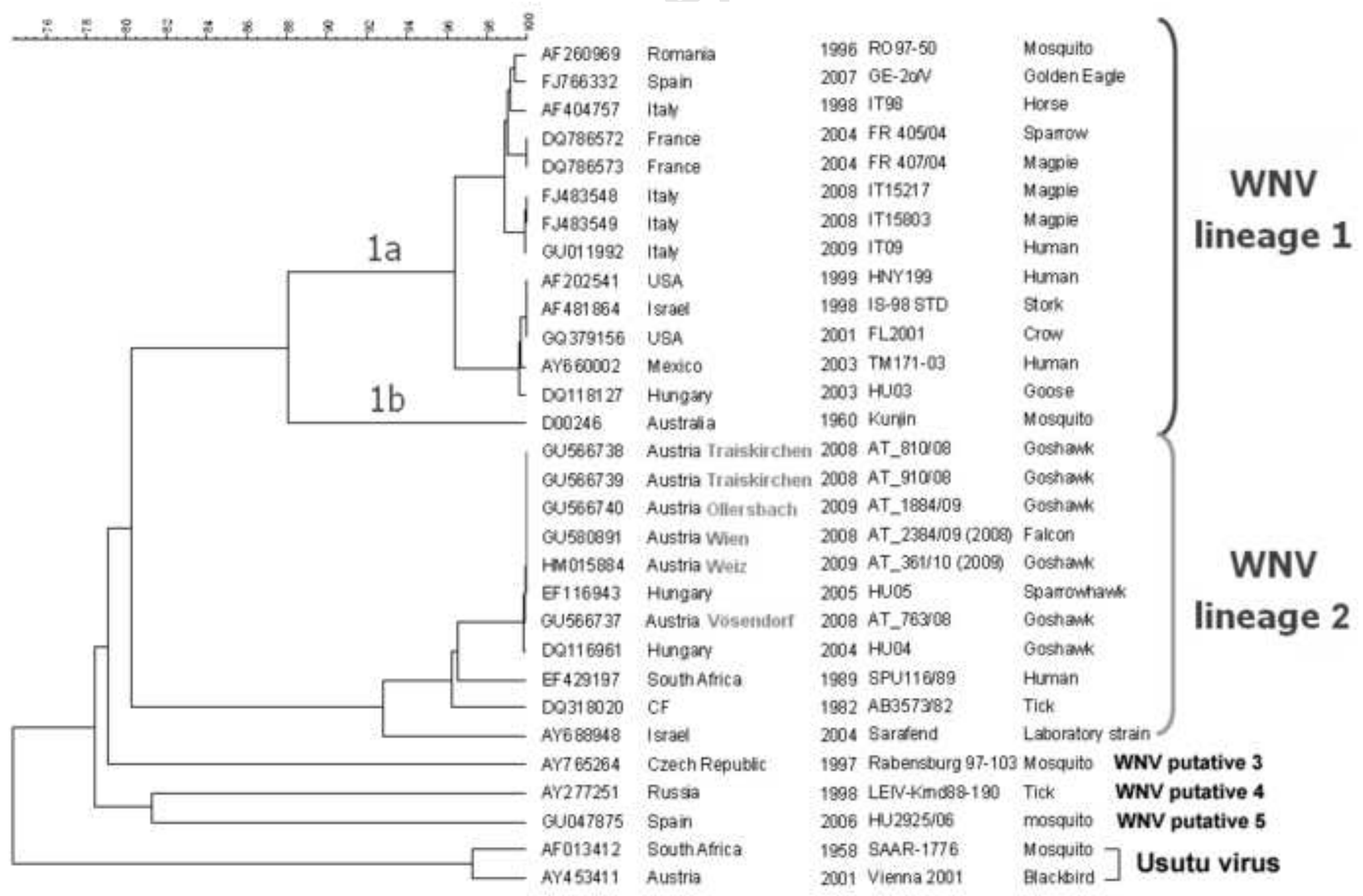


Click here to download high resolution image

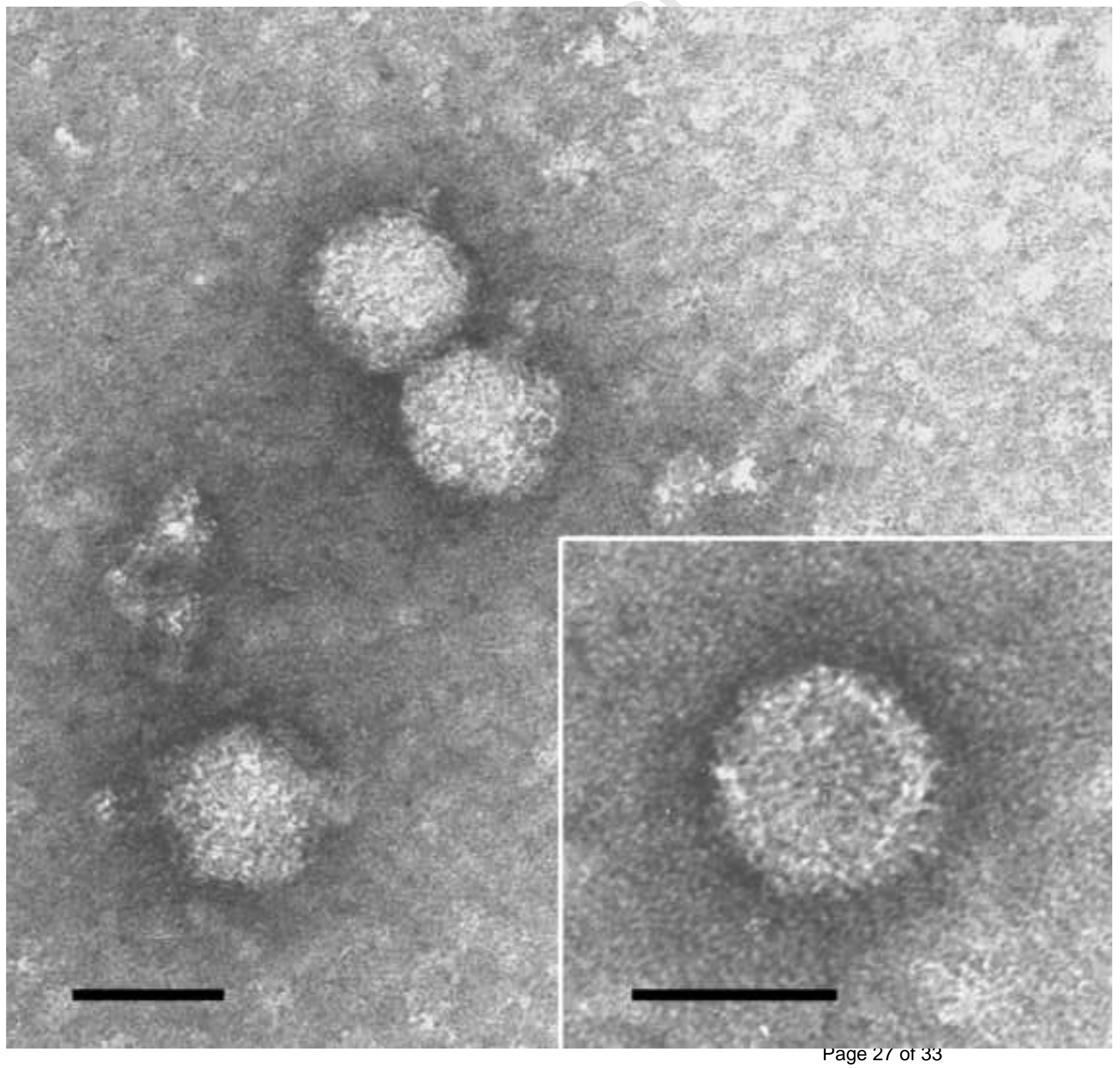




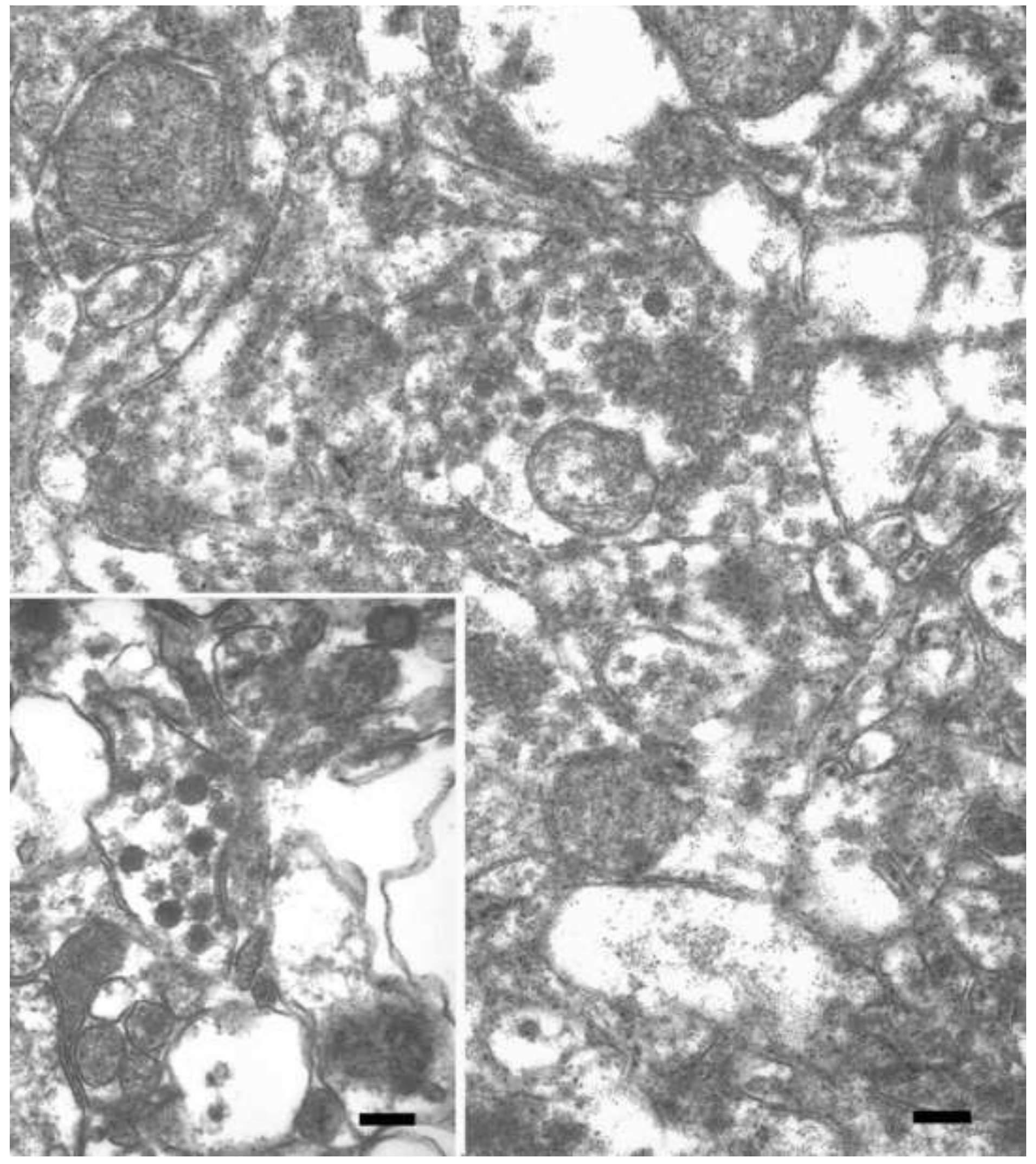




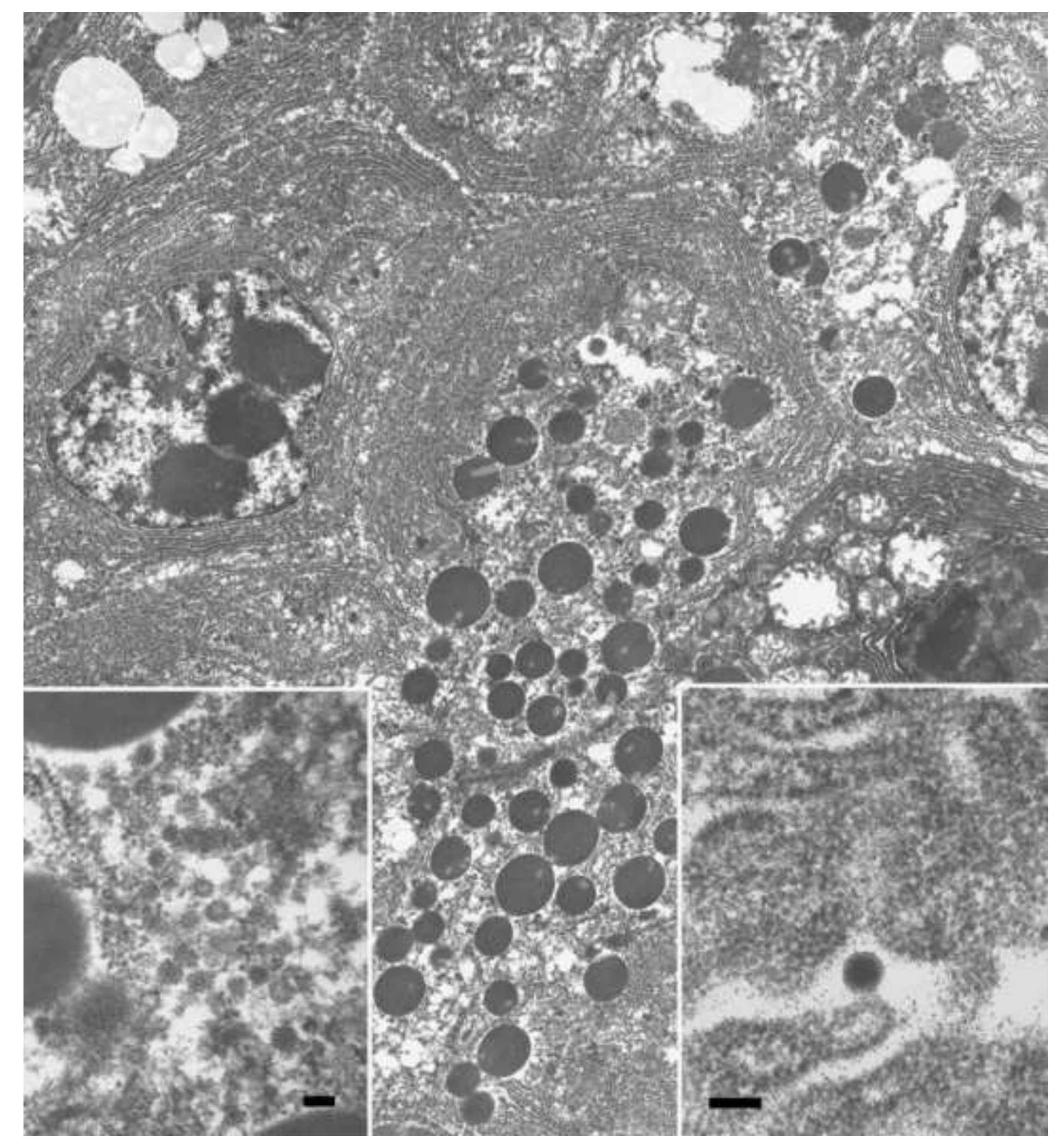




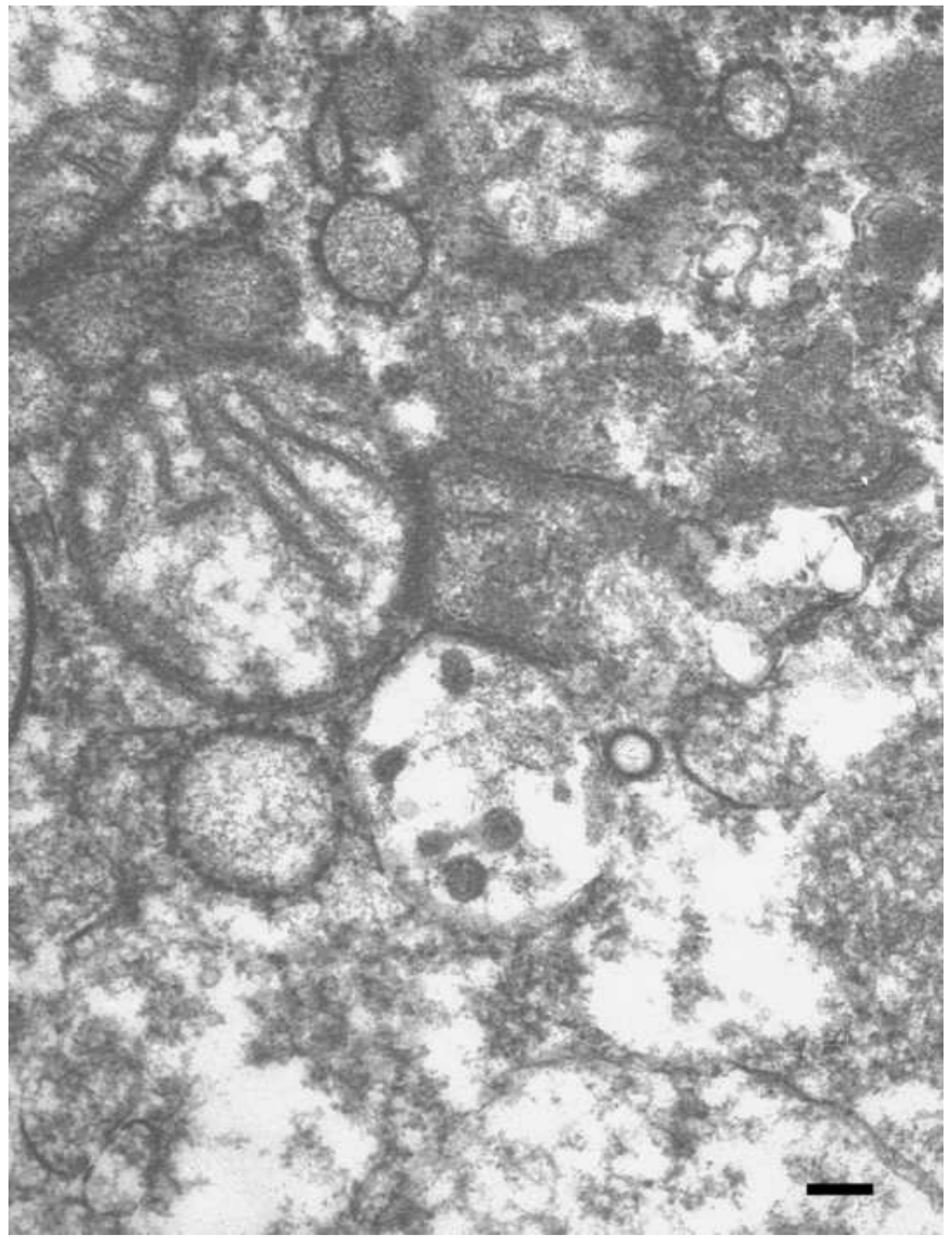



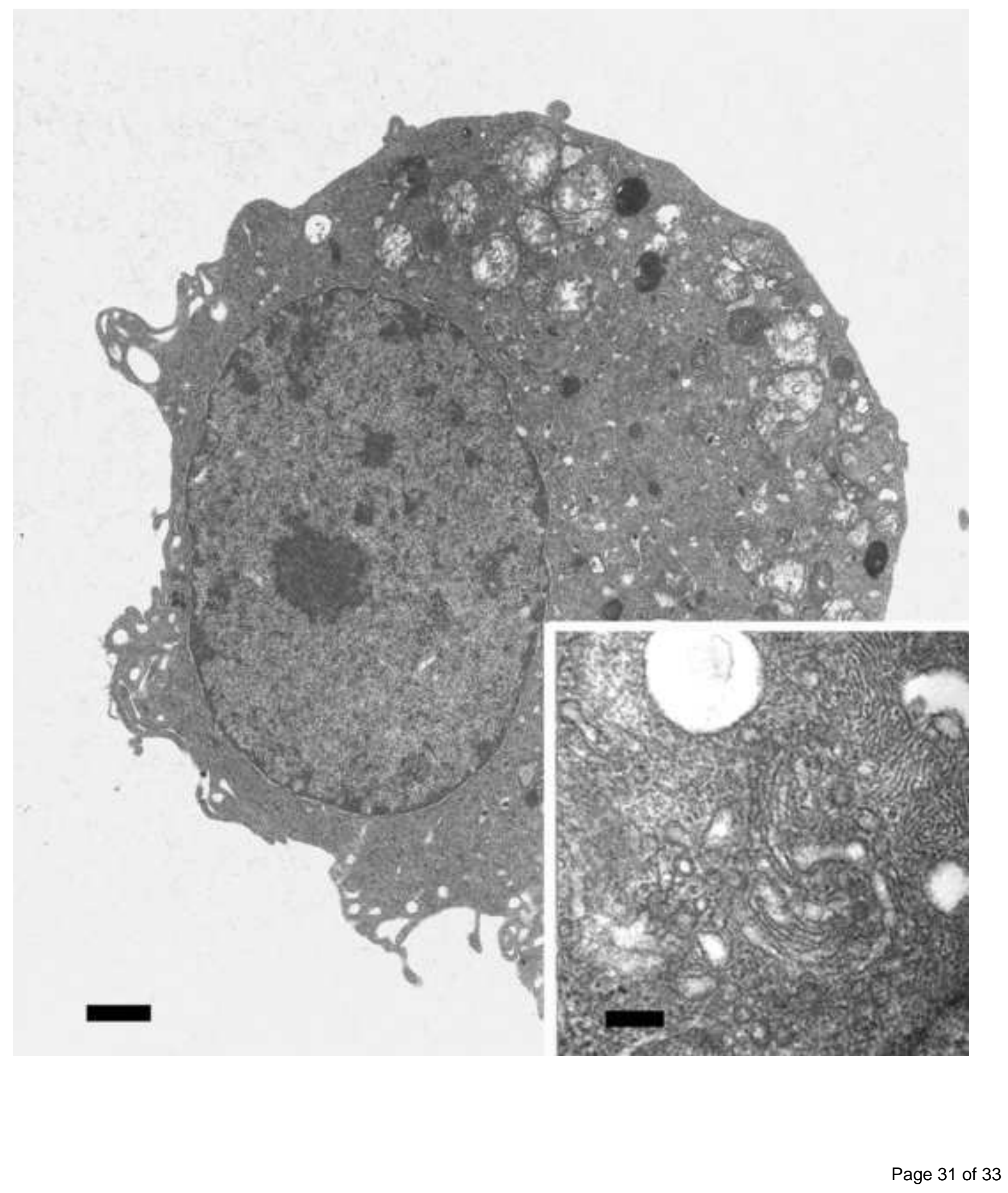


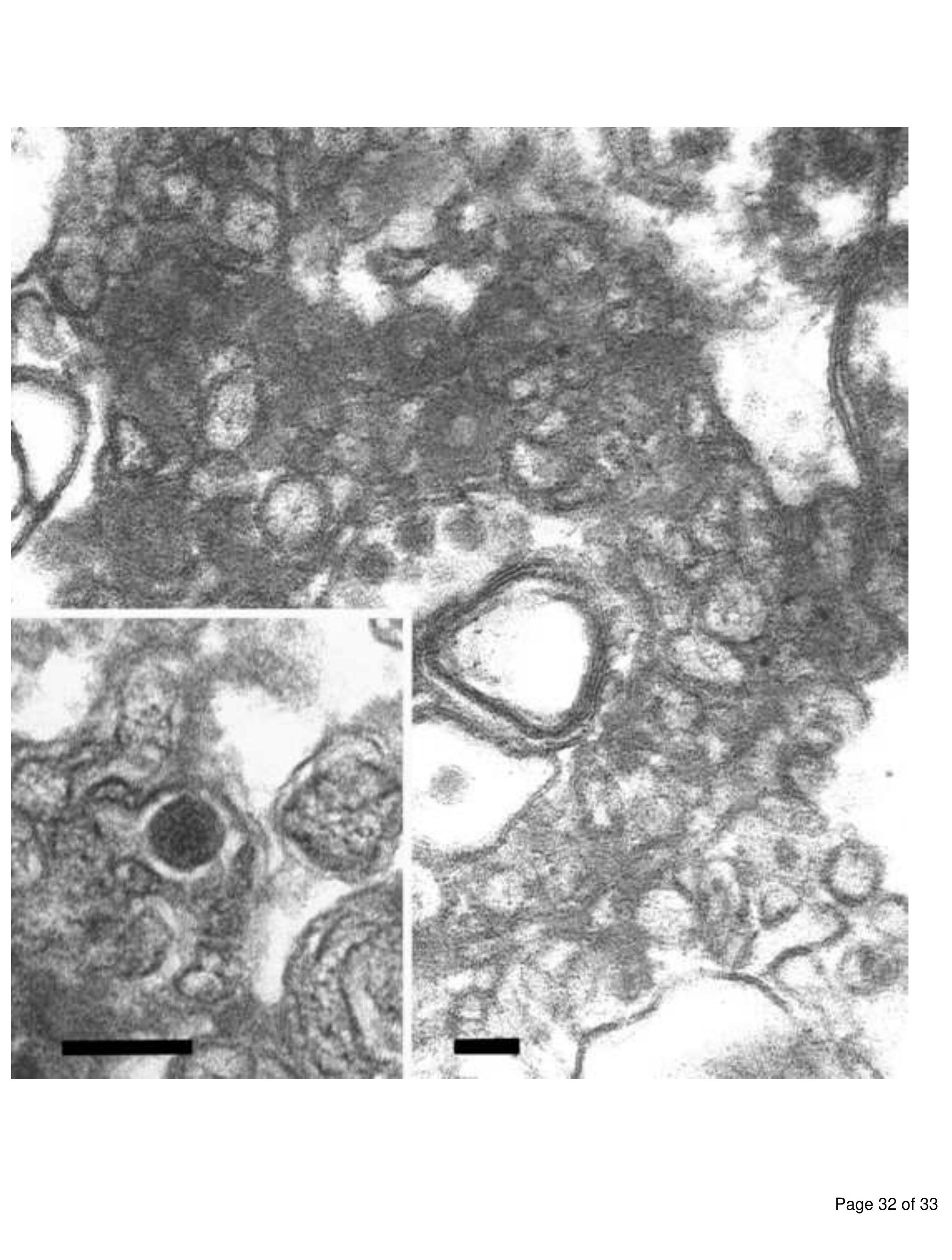

(2)

.

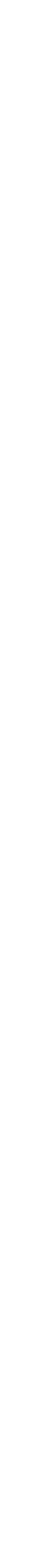




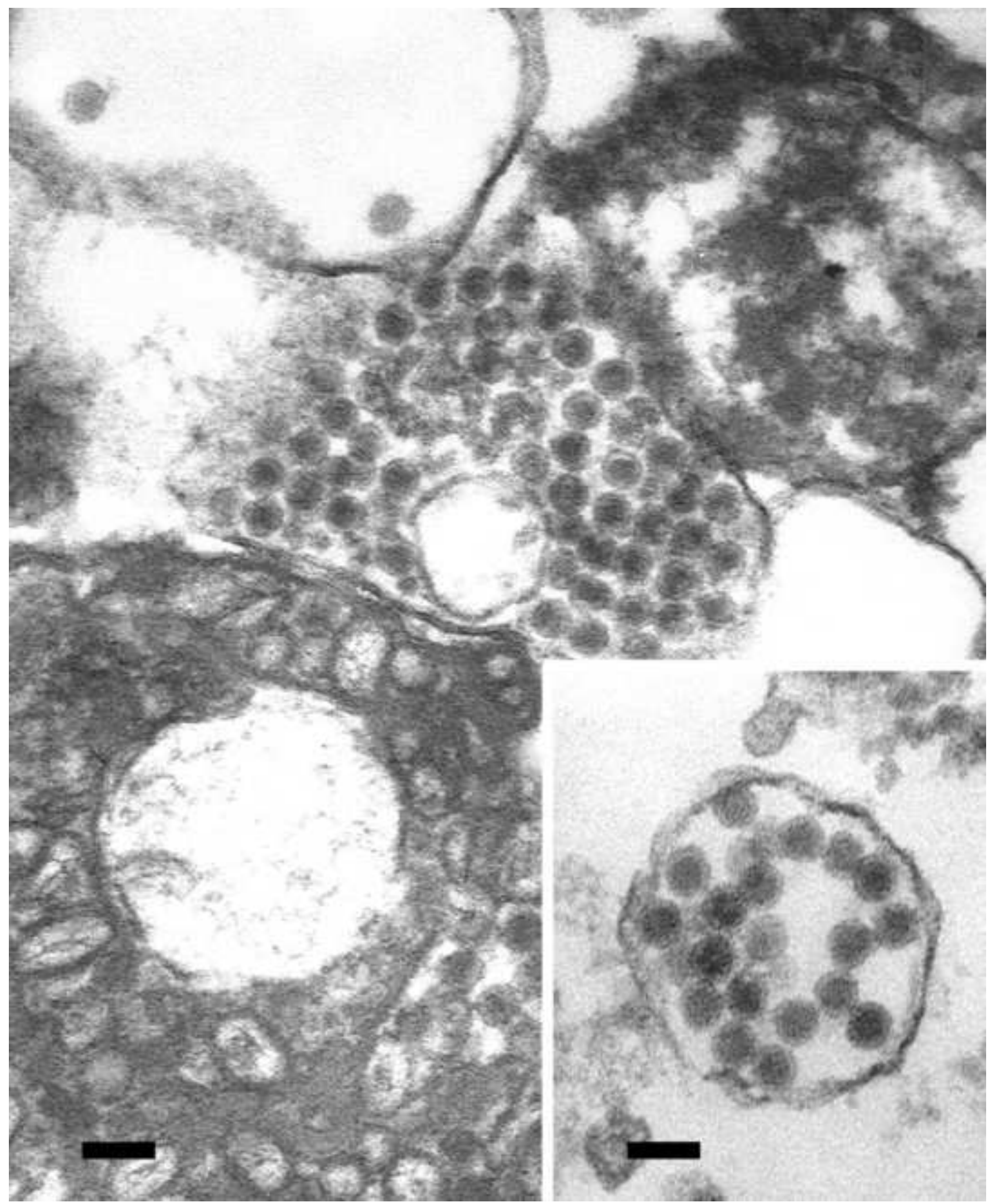

